\title{
Studies on the Interconversion of Hexoses in Diabetes Mellitus
}

I. Metabolism of Fructose and Galactose in Patients with Diabetes Mellitus

By

\section{Teruo UEMATU}

The 1st Department of Internal Medicine, Osaka University, Medical School

(Director: Prof. T. Yoshida)

It is well known that fructose and galactose are easily converted to glucose in the body. Various foods contain fructose and galactose. Therefore, it may be important, from the nutritional standpoint, to evaluate the ability of diabetics to utilize fructose and galactose. Present study dealt with the utilization of fructose and galactose in patients with diabetes mellitus and relation between the utilization of these sugars and the types of disease, age and complication of patients. The results were as follows.

(1) Diabetics showed enhanced interconversion from fructose to glucose and disturbance in the utilization of galactose.

(2) Disturbance of galactose utilization was more marked in patients with severe diabetes mellitus.

(3) The conversion of fructose to glucose was more marked in thin patients and younger patients.

(4) Disturbance of glactose utilization was more marked in older patients and in those with complications.

(5) The elevation of blood pyruvate level following the administration of fructose or galactose was found to be almost the same in diabetics as in normals. However, the rise in blood pyruvate level persisted longer in diabetics than in normal adults. 


\title{
糖尿病の糖質相互転換に関する研究
}

\author{
1。糖尿病患者の果糖及びガラクトーズ代謝
}

大阪大学医学部吉田内科 (主任 吉田常雄教授)

植松輝 夫

\section{緒言}

果糖及びガラクトーズ (Gal.) は日常食品中に多く含忠れブドウ糖に次ぐ重要糖質であるが，その糖尿病に 於ける栄養学的意義については尚検討を要する.

糖尿病患者に於ける果糖代謝については以前より検討され，果糖は他の糖質よりも良く利用されることが 知られている。しかし Gal. 代謝に関する報告は尚少なく，僅かに最近の Alslev の成績がみられるのみで ある1).

一方果糖及び Gal. は生体内で容易にブドウ糖に転換する事が知られている。乙の点に鑑み，私は糖尿病 患者について果糖及び Gal. 負荷試験を行ない，之等糖質の利用及びブドウ糖への転換状況を検索すると共 に，更に年令，体型，合作症などとの関連をむ種々検討して之等糖質の糖尿病に於ける栄養学的意義ならび に本症病態生理の解明に資するため次の如き実験を行なつた。

\section{実 験 方 法}

\section{1. 被験者}

健常人として糖尿を見ず血糖正常で，かつ肝機能検查其他に異常を認めない成人10名を選んだ（果糖負葆 試験，Gal. 負荷試験何れも5 名づつ).

糖尿病㭧者は当内科の入院及び外来患者 45 名で（果糖負荷試験 23 名，Gal. 負荷試験 22 名），既に食䬣療法 又は諸薬剂により治療中の患者は除外した。

又患者は年令別，体型別，合併症の有無に上り分類した，年令別では40才以下を若年型，40〜60才を中年 型，60才以上を老年型とし，体型別では Broca 指数にもとづき110以上を肥満型，90以下をるいそう型，90 〜110のものを中間型とした，又合併症として高血圧症は持続的に最高血圧 $150 \mathrm{mg} / \mathrm{d} 1$ 以上か又は最低血压 90 $\mathrm{mg} / \mathrm{d} \mathrm{l}$ 以上のあのを選び，動脈硬化症は眼底所見，乙線所見，橈骨動脈の性状，E.K.G. 等により判定し， 多発性神経炎は疼痛, 知覚異常, 腱反射異常等により診断した。患者は之等 3 種の合併症を有するものと, 全く合併症を伴なわないものとの 4 群に分類した，尚刘照として重症肝実質性疾患患者各 5 例についても果 糖及び Gal. 負荷試験を行つた。

\section{2. 測定法}

早朝空腹時体重 $1 \mathrm{~kg}$ 当り $1 \mathrm{~g}$ の果糖又は Gal.を水約 $300 \mathrm{cc}$ と共に投与し, 投与前及び投与後 30 分, 60分, 90 分，120分の計 5 回採血し，各々につき総糖質，果糖又は Gal. を測定した。尚健常人及び糖尿病患者の

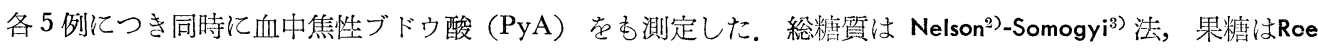

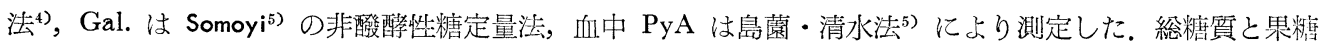
又は Gal. との差を以て血中ブドウ糖值とした. 又負荷後各採血時間に於ける総糖質浱度，ブドウ糖浱度， 果糖濃度，Gal. 濃度につき，負荷前のそれらとの差を夫久算出し之等を算術平均せるものを総糖質，ブド ウ糖，果糖乃至 Gal. 平均上暑濃度とした。 


\section{実 験 成 績}

\section{1. 果糖代謝}

\section{（1），健常人，䀒疾患患者及び糖尿病患者の果糖負荷試験}

第 1 表の如 $<$, 負荷後果糖平均上昇濃度は健常人 5 例平均 $7.4 \pm 2.0 \mathrm{mg} / \mathrm{dl}$, 肝疾患㭧者 5 例平均 $19.0 \pm$ $4.5 \mathrm{mg} / \mathrm{dl}$ ，糖尿病患者 23 例平均 $8.2 \pm 3.9 \mathrm{mg} / \mathrm{dl}$ で，果糖処理能は肝疾患ではかなりの障害がみられたが， 糖尿病では健常人と略々同様であつた，又ブドウ糖平均上昇濃度は健常人平均 $14.0 \pm 5.2 \mathrm{mg} / \mathrm{dl}$, 䀒疾患患 者平均 $13.0 \pm 1.0 \mathrm{mg} / \mathrm{dl}$ であるに対し，糖永病患者では $36.0 \pm 24.1 \mathrm{mg} / \mathrm{dl}$ であり $(\mathrm{Pr}<0.05)$ ブドウ糖への 転換の交進がみられた。等を図示すれば第 1 図の如くである。（第 1 表）(第 1 図)

第 1 表 健常人及び糖尿病患者の果糖負荷試験 果糖 $1 \mathrm{~g} / \mathrm{kg}$ 経口負荷後糖質平均上昇濃度 (30分毎 4 回採血平均)

\begin{tabular}{|c|c|c|c|c|c|c|c|c|}
\hline & & & \multirow{2}{*}{$\begin{array}{l}\text { 例 } \\
\text { 数 }\end{array}$} & \multirow{2}{*}{$\begin{array}{c}\text { 空腹時血糖 } \\
(\mathrm{mg} / \mathrm{dl} \text { ) }\end{array}$} & \multicolumn{4}{|c|}{ 平均上昇濃度 $\quad(\mathrm{mg} / \mathrm{dl})$} \\
\hline & & & & & 総 糖 質 & ブドウ 糖 & 果 & 糖 \\
\hline 健 & 常 & 人 & 5 & $77 \pm 8.0$ & $21.4 \pm 4.4$ & $14.0 \pm 5.2$ & & \pm 2.4 \\
\hline 糖 & 尿 & 病 & 24 & $161 \pm 52.0$ & $44.3 \pm 24.4$ & $36.0 \pm 24.1$ & 3 & \pm 3.9 \\
\hline 肝 & 疾 & 恵 & 5 & $85 \pm 4.0$ & $32.0 \pm 5.4$ & $13.0 \pm 1.0$ & & \pm 4.5 \\
\hline
\end{tabular}

（2）糖尿病思者の空腹時血糖

\section{と果糖負荷試験}

第 2 図の如 $<$, 果糖平均上昇 濃度は糖尿病の軽重に拘わらず 全例 $20 \mathrm{mg} / \mathrm{dl}$ 以下に偏在するの が見られた。ブドウ糖平均上昇 濃度に就ては空腹時血糖高い例 にその大なるものが多かつたが 両者の間に著明な相関はみられ なかつた $(\gamma=+0.22)$ (第2図).

(3) 糖尿病患者の年令と果糖

\section{負荷試験}

果糖平均上昇濃度は若年型 3 例平均 $5.7 \pm 0.5 \mathrm{mg} / \mathrm{dl}$, 中年型 16 例平均 $8.1 \pm 4.1 \mathrm{mg} / \mathrm{dl}$, 老年 型 4 例平均 $8.5 \pm 2.2 \mathrm{mg} / \mathrm{dl}$ で殆 んど差を認めなかつた. 之に対 しブドウ糖平均上昇濃度は若年 型平均 $48.7 \pm 15.8 \mathrm{mg} / \mathrm{dl}$, 中年 型平均 $31.4 \pm 25.0 \mathrm{mg} / \mathrm{dl}$, 老年 型平均 $44.8 \pm 10.9 \mathrm{mg} / \mathrm{dl}$ で, ブ ドウ糖への転渙は若年型>老年 型>中年型の順に著明であつた が統計学的には有意の差を示さ なかつた (第 3 図).

（4）糖尿病思者の体型と果糖
第 1 図健常人及び糖㲾病患者の果糖負荷試験 （果糖 $1 \mathrm{~g} / \mathrm{kg}$ 経口負荷後血糖曲線）

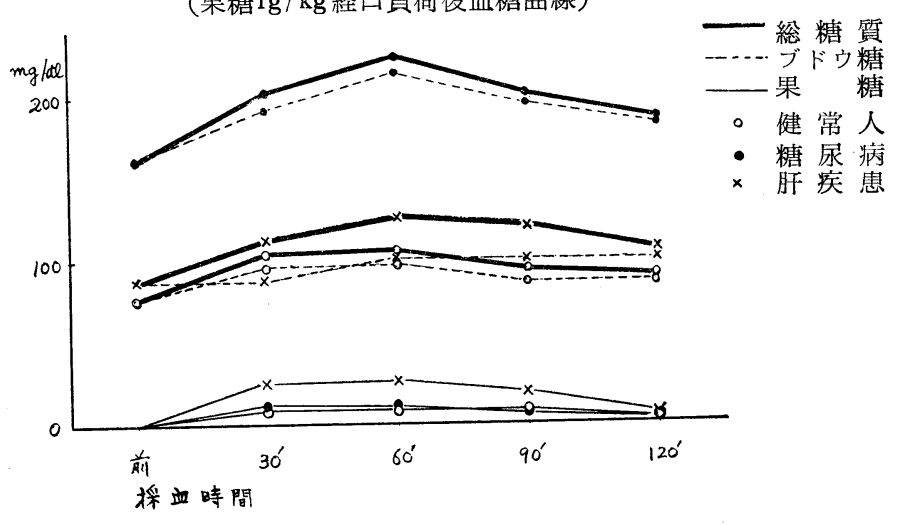

第 2 図空腹時血精と果糖負荷試験との相関 （果糖負荷後糖質平均上昇濃度と空腹時血糖との相関）

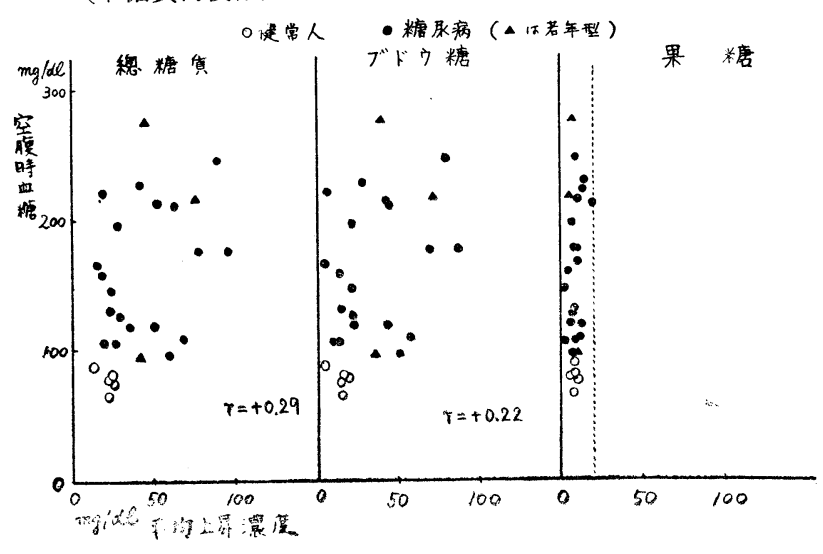

箱34巻 第11号 


\section{負荷試験}

第 4 図に示す如く，果糖平均 上昇濃度はるいそう型 3 例平均 $6.0 \pm 0.8 \mathrm{mg} / \mathrm{dl}$ ，中間型14例平 均 $8.8 \pm 3.6 \mathrm{mg} / \mathrm{dl}$, 肥満型 6 例 平均 $8.0 \pm 4.9 \mathrm{mg} / \mathrm{dl}$ で三者の間 に大差はみなかつた. ブドウ糖 平均上㫧濃度はるいそう型平均 $53.7 \pm 13.2 \mathrm{mg} / \mathrm{dl}$, 中間型平均 $35.4 \pm 24.1 \mathrm{mg} / \mathrm{dl}$, 肥満型平均 $28.7 \pm 15.6 \mathrm{mg} / \mathrm{dl}$ でブドウ糖へ の転換はるいそう型が最も著明 で中間型之につぎ肥満型は最も 軽度であつた。るいそう型と肥 満型との差は統計学的にも有意 であつた $(\operatorname{Pr}<0.05)$. (第 4 図)

\section{（5）合併症と果糖負荷試験}

果糖及びブドウ糖平均上昇濃 度は合併症を伴わないもの8例 平均では夫々 $7.7 \pm 5.0 \mathrm{mg} / \mathrm{dl}$ ， $30,6 \pm 20.0 \mathrm{mg} / \mathrm{dl}$, 動脈硬化症合 併例 9 例平均では夫々 $8.5 \pm 2.6$ $\mathrm{mg} / \mathrm{dl}, 39.5 \pm 24.9 \mathrm{mg} / \mathrm{dl}$, 高 血圧症合併例 8 例平均では夫々 $9.2 \pm 2.9 \mathrm{mg} / \mathrm{dl}, 32.9 \pm 20.3 \mathrm{mg} /$ $\mathrm{dl}$ ，多発性神経炎合併例 4 例平 均では夫々 $6.5 \pm 3.6 \mathrm{mg} / \mathrm{dl}$ ， $28.3 \pm 9.1 \mathrm{mg} / \mathrm{dl}$ であつた。即 ち果糖平均上昇濃度は高血庄症 合併例でやや高いが，一般に果 糖処理能は合併症の有無により 大差は認められない，又ブドウ 糖への転換屯動脈硬化症合併例 でやや六進したが，一般に合併 症の有無により有意の差は認め られなかつた。（第 5 図）

（6）果糖負荷待血中PyAの動 向

第 6 図の如く血中 PyA 濃度 は健常人 5 例平均 $1.07 \pm 0.31 \mathrm{mg}$ $/ \mathrm{dl}$ ，糖尿病患者 5 例平均 1.31 $\pm 0.18 \mathrm{mg} / \mathrm{dl}$ であり，糖㽷病思 者で高值を示した，又舀糖負荷
第 3 図糖尿病患者の年令々果糖負荷試験

（果糖 $1 \mathrm{~g} / \mathrm{kg}$ 経口負荷）

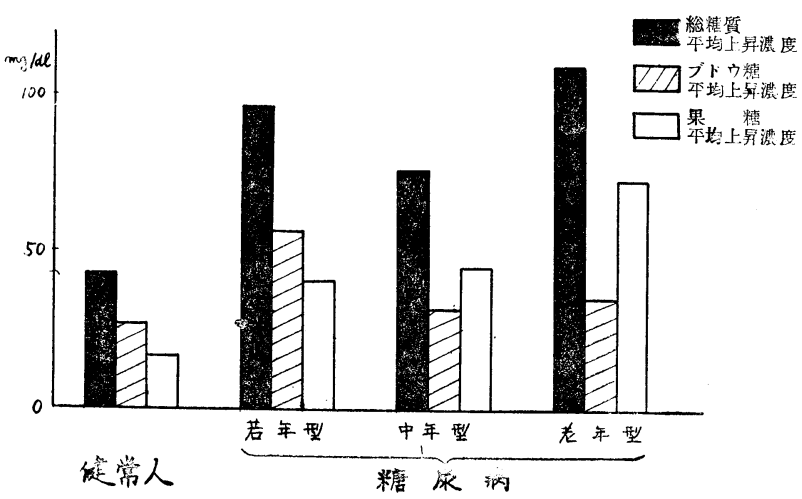

第 4 図糖尿病患者の体型と果糖負荷試験

(果糖 $\lg / \mathrm{kg}$ 経口負荷)

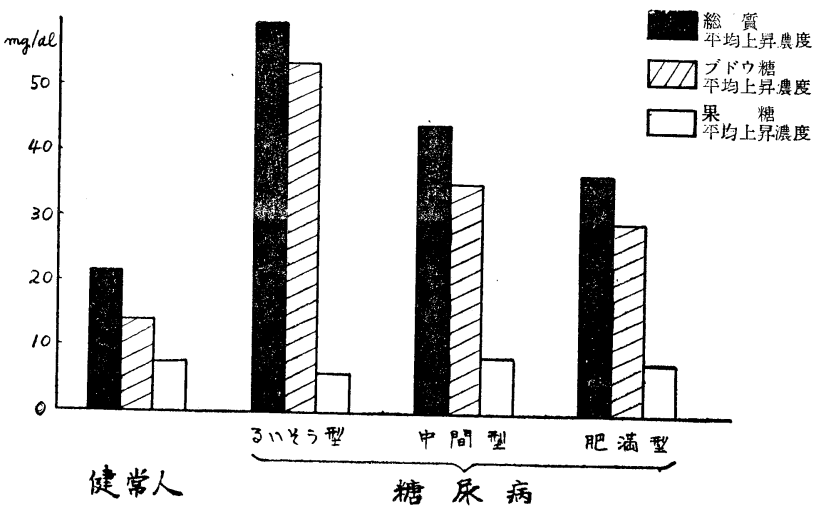

第 5 図糖尿病患者の合併症と果糖負荷試験 （果糖 $\lg / \mathrm{kg}$ 経口負荷）

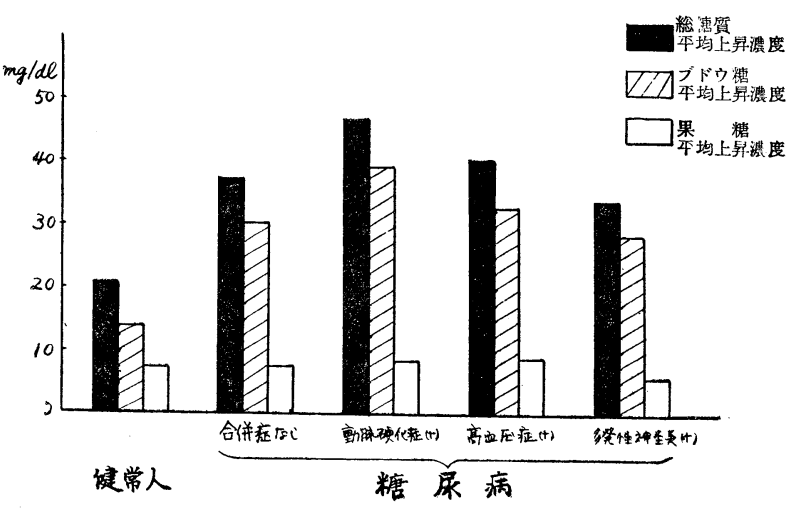

符34卷 第11学 
後血中 PyA 濃度は健常人では 30 分値 $2.31 \pm 0.38 \mathrm{mg} / \mathrm{dl}, 60$ 分 值 $2.34 \pm 0.32 \mathrm{mg} / \mathrm{dl}, 90$ 分值 2.29 $\pm 0.29 \mathrm{mg} / \mathrm{dl} ， 120$ 分值 1.79 土 $0.07 \mathrm{mg} / \mathrm{dl}$ であつた. 之に対 し糖氺病患者では30分值 $2.47 \pm$ $0.47 \mathrm{mg} / \mathrm{dl} ， 60$ 分値 $2.93 \pm 0.45$ $\mathrm{mg} / \mathrm{dl}, 90$ 分值 $2.68 \pm 0.38 \mathrm{mg} /$ $\mathrm{dl}, 120$ 分值 $2.40 \pm 0.09 \mathrm{mg} / \mathrm{dl}$ で, 最高值は健常人, 糖尿病恵者何 れも負荷後60分で，糖㽷病患者 に於て稍高く爾後に於てはPyA の停滞頙向を示した.（第 6 図）

\section{Gal. 代謝}

第 6 図 糖質経口負荷時の血中焦性ブドウ酸の動问

（各糖質 $1 \mathrm{~g} / \mathrm{kg}$ 経口負荷後 30 分毎 4 回採血）

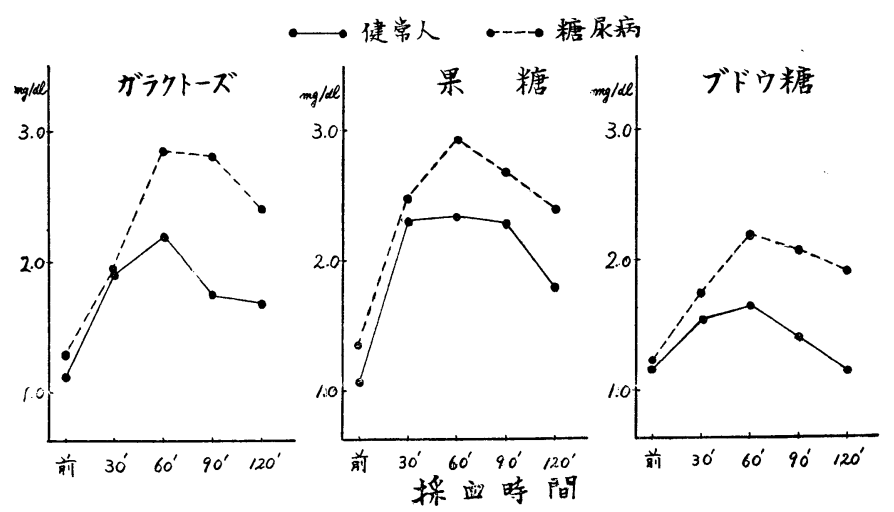

（1）健常人, 肝疾患患者及び糖尿病患者の Gal. 負荷試験

Gal. 平均上昇濃度は健常人 5 例平均 $16.6 \pm 5.7 \mathrm{mg} / \mathrm{dl}$ であるに対し，糖家病贯者 22 例平均では50.5 25.9 $\mathrm{mg} / \mathrm{dl}$ で高度の Gal. 血中停滞が㒻られた. 両者の差は統計学的に有意であつた $(\operatorname{Pr}<0.01)$. 又肝疾患患者 5 例平均は $79.4 \pm 17.3 \mathrm{mg} / \mathrm{dl}$ で Gal. 血中停滞湏可は更に顕著であつた. ブドウ糖平均上昇濃度は健常人平 均 26.8 土 $15.1 \mathrm{mg} / \mathrm{dl}$, 糖录定㤩者平均 $33.4 \pm 31.8 \mathrm{mg} / \mathrm{dl}$ ，肝矣患患者平均 $11.0 \pm 8.4 \mathrm{mg} / \mathrm{dl}$ で唐录病患者に

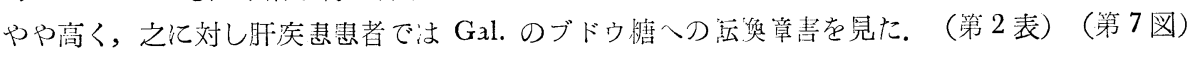

第 2 表 健常人及び糖尿病患者のガラクトーズ負荷試験 ガラクトーズ $1 \mathrm{~g} / \mathrm{kg}$ 経口負荷後糖質平均上昇濃度 (30分每 4 回採血平均)

\begin{tabular}{|c|c|c|c|c|c|c|c|}
\hline & & & \multirow{2}{*}{$\begin{array}{l}\text { 例 } \\
\text { 数 }\end{array}$} & \multirow{2}{*}{$\begin{array}{c}\text { 空腹時血糖 } \\
(\mathrm{mg} / \mathrm{dl})\end{array}$} & \multicolumn{3}{|c|}{ 平均上昇濃度 $(\mathrm{mg} / \mathrm{dl})$} \\
\hline & & & & & 総 糖 質 & ブドウ糖 & ガラクトーズ \\
\hline 健 & 常 & 人 & 5 & $64 \pm \quad 4$ & $43.4 \pm 14.7$ & $26.8 \pm 15.1$ & $16.6 \pm 5.7$ \\
\hline 糖 & 尿 & 病 & 22 & $208 \pm 105$ & 88.8 上 33.8 & $38.3 \pm 31.8$ & $50.5 \pm 25.9$ \\
\hline 肝 & 疾 & 㭧 & 5 & $80 \pm 14$ & $90.4 \pm 19.6$ & $11.0 \pm 8.4$ & $79.4 \pm 17.3$ \\
\hline
\end{tabular}

\section{(2) 糖尿病患者の空腹時血糖}

\section{と Gal. 負荷試験との相関}

第 8 図に示す如く, 空腹時血 糖と総糖質平均上昇濃度又は Gal. 平均上昇濃度との間には かなりの相関が見られた。この 際若年型糖尿病例では一定の傾 向を見なかつたので之を除外し て相関係数を求めたが夫々 $\mathrm{r}=$ $+0.61(\operatorname{Pr}<0.01), \quad r=+0.57$ $(\operatorname{Pr}<0.01)$ であつた. ブドウ 糖平均上昇濃度との間には相関 を認めなかつた（第 8 図）
第 7 図健常人及び糖尿病患者のガラクトーズ負荷試験 （ガラクトーズ $1 \mathrm{~g} / \mathrm{kg}$ 経口負荷後血糖曲線）

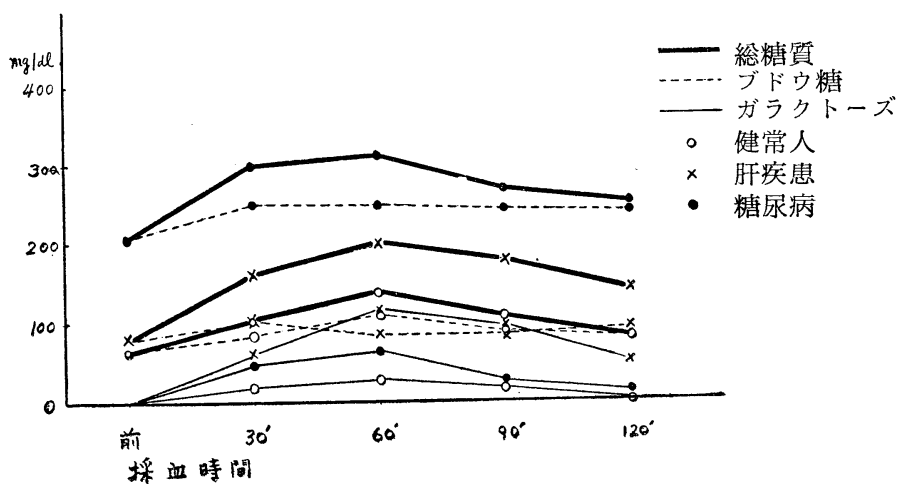

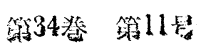


（3）糖尿病患者の年令别と

\section{Gal。負荷試験}

若年型 5 例，中年型12例，老 年型 5 例について比較するに， 第 9 図に示す如くGal. 平均上 昇濃度は夫々若年型 $40.4 \pm 21.7$ $\mathrm{mg} / \mathrm{dl} ，$ 中年型 $45.3 \pm 22.6 \mathrm{mg} /$ $\mathrm{dl}$ ，老年型 $73.2 \pm 24.4 \mathrm{mg} / \mathrm{dl}$ で Gal. 血中停滞は老年型で最も 高度であり，若年型，中年型の 間には差がなかつた.ブドウ糖 平均上昇濃度は夫々若年型 57.4 $\pm 56.3 \mathrm{mg} / \mathrm{dl} ，$ 中年型 $31.6 \pm$ $15.9 \mathrm{mg} / \mathrm{dl}$ ，老年型 $35.4 \pm 13.0$ $\mathrm{mg} / \mathrm{dl}$ であり，ブドウ糖への転 換は若年型に於て最も高度であ つた. (第 9 図)

（4）糖尿病患者の体型别と

\section{Gal. 負荷試験}

Gal. 平均上昇濃度はるいそう 型 5 例平均 $55.0 \pm 252 \mathrm{mg} / \mathrm{dl}$, 中 間型10例平枃 $52.8 \pm 30.4 \mathrm{mg} / \mathrm{dl}$, 肥満型 7 例平均は $48.1 \pm 14.5$ $\mathrm{mg} / \mathrm{dl}$ であつた，又血中ブドウ 糖平均上昇濃度はるいそう型平 均は $35.6 \pm 13.6 \mathrm{mg} / \mathrm{dl}$ ，中間 平均は $33.0 \pm 16.7 \mathrm{mg} / \mathrm{dl}$, 肥满 型平均 $27.7 \pm 6.9 \mathrm{mg} / \mathrm{dl}$ であつ た. 即ち第10㓙汇見る如く, Gal. 中停滞, ブドウ糖への転渙共に るいそう型で最も著明で，次い で中間型，肥満型の順であつた が，その差は僅かであり統計学 的に有意であるとは云へない. (第10図)

\section{（5）糖尿病患者の合併症と}

\section{Gal. 負荷試験}

Gal.及びブドウ糖平均上昇鋠 度は合併症を伴わぬすの 8 例平 均では夫々 $42.9 \pm 17.7 \mathrm{mg} / \mathrm{dl}$, $32.3 \pm 10.5 \mathrm{mg} / \mathrm{dl}$, 動脈硬化症 合併例 8 例平均では夫々 65.5 土 $27.7 \mathrm{mg} / \mathrm{dl}, 26.0 \pm 12.3 \mathrm{mg} / \mathrm{dl}$,
第 8 図 空腹時血糖とガラクトーズ負荷試験との相関 （ガラクトーズ負荷後糖質平均上昇濃度と空腹時血糖との相関）

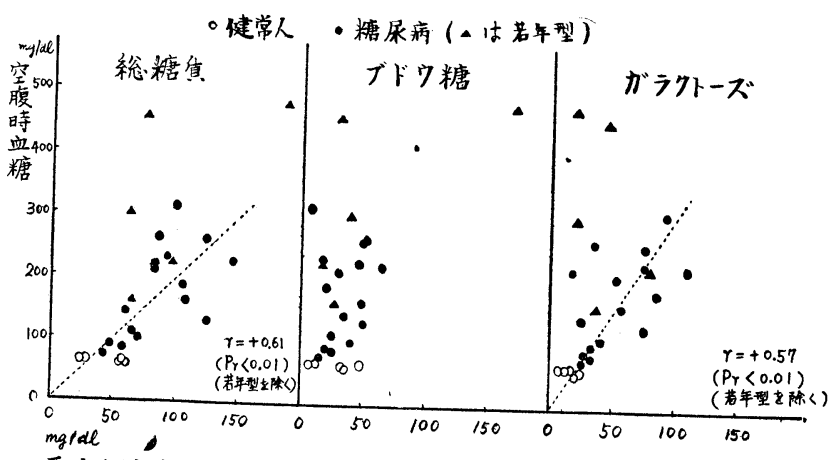

平均上㫒濃度

第9図 糖尿病患者の年令別とガラクトーズ負荷試験 (ガラクトーズ $1 \mathrm{~g} / \mathrm{kg}$ 経口負荷)

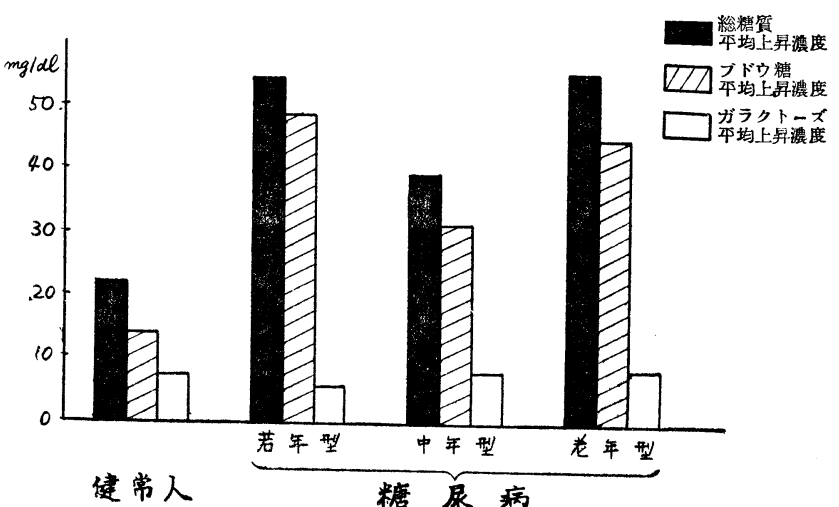

第10図 糖尿病患者の体型別とガラクトーズ負荷試験

（ガラクトーズ $\lg / \mathrm{kg}$ 経口負荷）

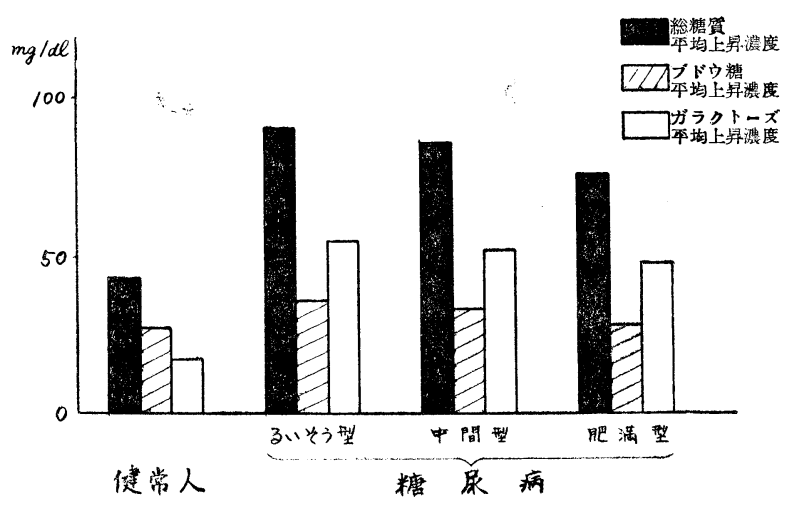

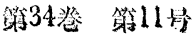


高血㾏症合併例 5 例平均では夫 々 $65.8 \pm 31.8 \mathrm{mg} / \mathrm{dl} ， 26.4 \pm$ $7.9 \mathrm{mg} / \mathrm{dl}$, 多発性神経炎合併 例 6 例平均では夫々 $59.0 \pm 23.3$ $\mathrm{mg} / \mathrm{dl}, 34.0 \pm 17.5 \mathrm{mg} / \mathrm{dl}$ であ つた。即ち合併症を伴う例讷合 併症を伴わない例に比し Gal. 血中停滞傾向は大であつたが， 夫々の合併症の間には殆んど差 なく，又ブドウ糖への転魥は合 併症には無関係であつた。（第 11図）

\section{Gal. 負荷 寺の血中 PyA} の動向
第11図 糖尿病患者の合併症とガラクトーズ負荷試铪 （ガラクトーズ $1 \mathrm{~g} / \mathrm{kg}$ 経口負荷）

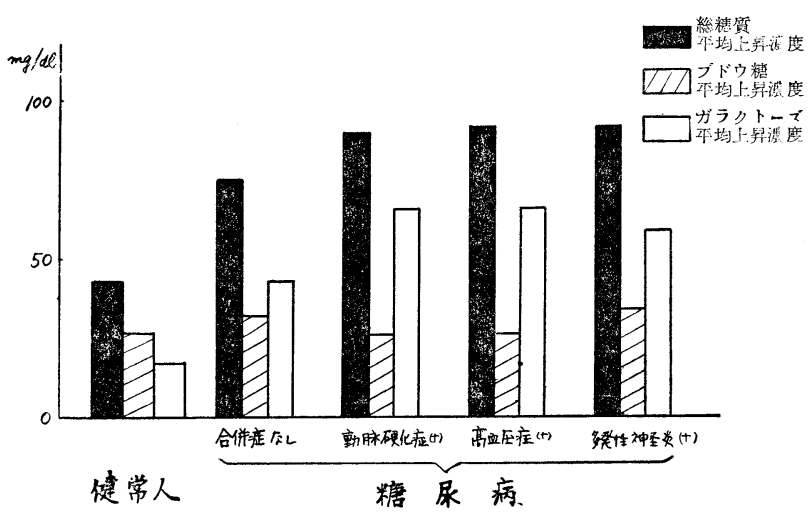

第 6 図の如く血中 PyA 濃度は健常人平均 $1.12 \pm 0.30 \mathrm{mg} / \mathrm{dl}$ ，糖冢病患者平均 $1.31 \pm 0.13 \mathrm{mg} / \mathrm{dl}$ であり

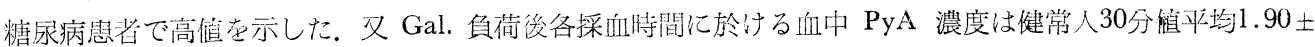
$0.73 \mathrm{mg} / \mathrm{dl} ， 60$ 分值平均 $2.20 \pm 0.90 \mathrm{mg} / \mathrm{dl} ， 90$ 分㙁痤均 $1.76 \pm 0.64 \mathrm{mg} / \mathrm{dl} ， 120$ 分做平均 $1.68 \pm 0.64 \mathrm{mg} / \mathrm{dl}$ であつた，糖㲾病患者では30分值平均 $1.94 \pm 0.40 \mathrm{mg} / \mathrm{dl} ， 60$ 分㑤平均 $2.85 \pm 0.71 \mathrm{mg} \mathrm{dl} ， 90$ 分值平均 $2.81 \pm$ $0.78 \mathrm{mg} / \mathrm{dl} ， 120$ 分值平均 $2.41 \pm 0.63 \mathrm{mg} / \mathrm{Al}$ であつた，即ち Gal. 負荷後血中 PyA は健常人，糖录病患者 共に負荷後60分に於て最高值虑示し，父闭者では糖家病の方がやや高徝であつたが，其後のPyA の動洞は 健常人では速やかに減少するに比し，糖尿病患者では停滞湏向が著明であつた。（第 6 図）

\section{総括並びに考按}

糖尿病患者に於ける果糖代謝については以前より検討が加えられ，その代謝障害は比較的㪕微であること

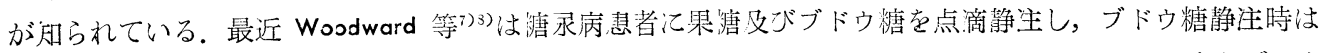
著明な高血糖とその血中停滞がみられるのに刘し，果糖ではその血中よりの消失速度は健常人と変らず，血 中ブドウ糖濃度上昇屯健常人より大であるが，ブドウ糖負荷時に及价ない事を指摘した。

又その際の血中 PyA，無幾燐つ勘句については，ブドウ糖負荷時血中 PyA 上昇は軽度且つ遅延し，無

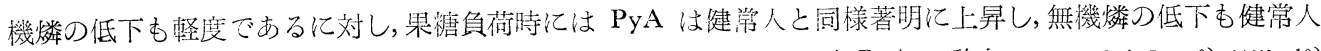
に比しやや小であるが速やか低下するを述べた. 果糖負荷後の血中 PyA の動间については Root ${ }^{9)}$, Miller $^{10)}$

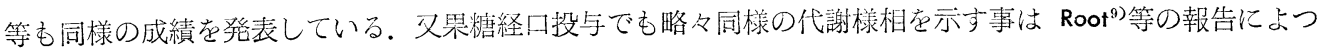
ても明らかである。

動物体内では果糖のブドウ糖への転換は容易に起るが，その大部分が拆藏で行われ，一部は小腸，婜臓で 屯行われる事が知られている11)-14)，糖永病㭧者に於ける果糖投与後の盘中ブドウ糖上昇の原因は，一つは

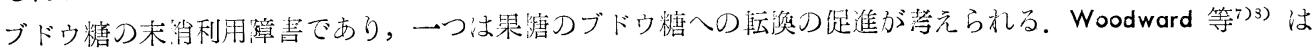
血中ブドウ糖上昇度は糖家病の重症度に略々平行して大となるとしている，私の成績であ空腹時血糖とブド ウ糖平均上昇浱度との間に著明な相関は認めなかつたが，重症のもの程大なるものが多かつた. 又患者の年 令別，体型別，合併症の有無と果糖代謝との関係につき検討を加えたが，ブドウ糖上昇は若年型，るいそう 型で大であり之等の病型では果糖のブドウ糖への轱換が九進しているものと落えられる。果糖代謝経路に就 いての最近の研究によれば，果糖は先づ fructokinase の作用により果糖-1一燐酸（以後燐酸をP と略す）と なり ${ }^{15)}$ ，次いで 1-Phosphofroctaldolase ${ }^{16)}$ そより Glyceraldehyde と Dihydroxyacetone phosphate に分解 されて Embden-Meyerhof の経路に入るとされている。一方 Cori 等 ${ }^{17}$ は白鼠肝から果糖-1-P $\rightarrow$ ブドウ糖一

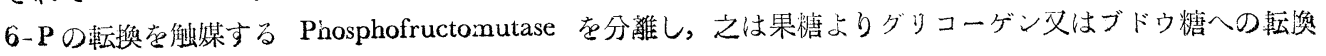


を促進し，果煻は正常動物肝でのよきグリコーゲン形成者であり，糖㲾病動物では Extraglucose の増加をも たらすと述べている，即ち果糖は肝藏隹於てブドウ糖とは独立した経路を経て利用されるのであり，糖尿病 に於て果糖はブドウ糖よりも良く利用されるが，ブドウ糖への転換む大である事が想像される。

糖尿病の Gal. 代謝については最近 Alslev 等1)の報告がある。即ち Alslev 等は健常人及び糖尿病患者に 体重 $1 \mathrm{~kg}$ 当り $1 \mathrm{~g}$ の Gal. を投与して血中 Gal., ブドウ糖，PyA., 乳酸の動向を検索した結果，Gal. 代謝は 健常人と糖冢病では異ならないと云う成績を報告した。然しながら私が同様体重 $1 \mathrm{~kg}$ 当り $1 \mathrm{~g} の \mathrm{Gal}$.を糖 尿病患者任経口投与し Gal. 代謝在検索した結果では，糖家病患者では Gal. 利用障害が見られ，而も糖尿 病の重症度とかなりの相関を認めた。この際血中ブドウ糖は健常人，肝疾患患者に比し糖尿病で上昇やや大 でブドウ糖への転換の克進も考えられる。

Park，Johnson ${ }^{18)}$ は内藏除去ラットにブドウ糖及び Gal. を点滴静注し，之等の未情利用に対するインシュ リンの影響价て検討し，インシュリンはブドウ糖及び Gal. の細胞膜透過啀を促すととを立証したが， 此の事実はインシュリンの絶対的乃至相刘的欠乏を原因とする糖永病代於て Gal. 未捎利用障害の存在を示

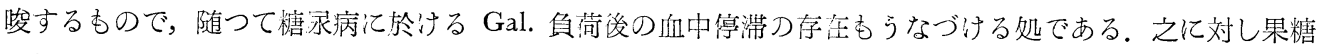
の細抱膜透過生がインシュリンの影暨を受けない事仗 Gammertoft 等199の明らかてした処である。

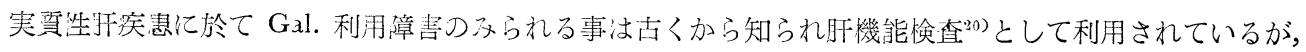
最近の Alslev"1) の研究でも肝疾貟では健常人に比し Gal. 投与後血糖曲線は高く，Gal. 血中停滞，乳酸， PyA の上昇遅延及び血中停滞を見ている。私が対照として行つた実幊洼肝突患患者列でも血中 Gal. 濃度

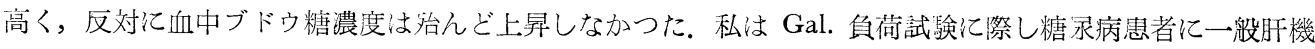
能倹査を実施し，グロス反芯異常 $16 \%$ ，Kunkel 硫㧎亚站反芯異常 $5 \%$ ，プロムサルファレイン試験異常の

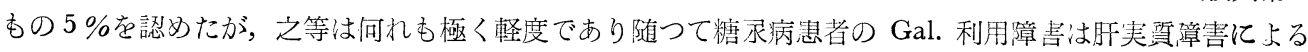
むのとは考えられず糖尿病固有の代謝異常と見做される。

Gal. 代謝む主として肝蔵で行われるが，その最初の段炛は Gal. が燐酸化されて Gal.-1-P 亿なる反応で

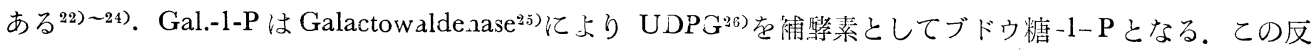

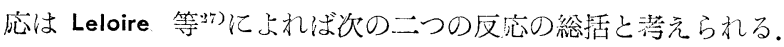

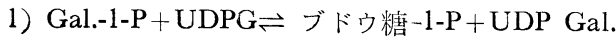

2) UDP Gal. $\rightleftharpoons$ UDPG

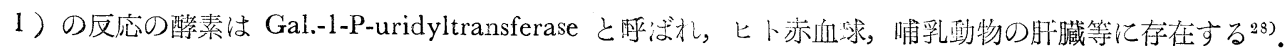
2 ) の反応在行引醉素は UDP Gal.-4-epimerase ${ }^{29300}$ である.

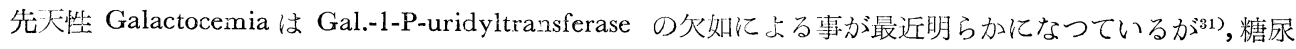

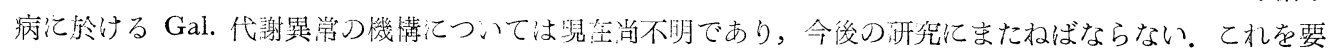

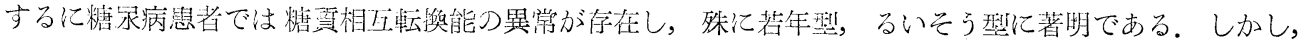
Gal. 負荷後の血中停滞は老年琹行最す著明であつた。かくの吅き若年型及び老年型糖冢病の Gal. 代謝異 常は食餌療法の問題とも関聯して注意を要するものと考えられる.

\section{結論}

健常人 5 例及び䌅永病患者 23 列に果糖 $1 \mathrm{~g} / \mathrm{kg}$ を，健常人 5 例及び糖家病患省 22 例にGal. $1 \mathrm{~g} / \mathrm{kg}$ を経口

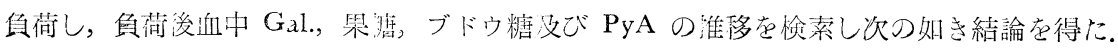

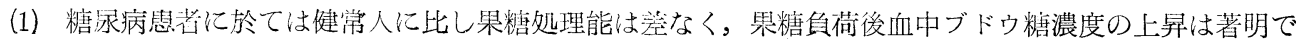
あり約 3 倍となつた。 又 Gal. 負荷試験では Gal. 血中停滞が著明であり平均上昇濃度は約 3 倍に達した。

（2）糖尿病㭧者の空䐘時血裾と果糖負荷後血中ブドウ糖濃度との間には著明な相関はみられなかつた。他

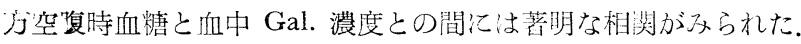

（3）年令別，体型別では果糖処理能は差を認めなかつたが，るいそう型，若年型で果糖負荷後血中ブドウ 䌅浱度は大であつた，Gal. 負荷後の血中停滞は老年型及びるいそう型に著明であつたが，その祭のブドウ 
糖濃度上昇は若年型，るいそう型で大であつた。

（4）合併症についてはその有無により果糖負荷試験では差なく，Gal. 血中停滞は合併症あるものの方が 大であつた。

（5）血中 PyA の動向は何れの場合にも健常人と同程度に上昇し，負荷後60分で最高值に達したが其後 血中停滞傾向を見た.

稿を終るにあたり御指導を睗わつた恩師吉田教授ならびに王子助教授に厚く御礼申上げます。また終始御 鞭撻下さつた和田講師に深謝すると共に御協力戴いた教室同僚諸氏に感謝します。

\section{主 要 文 献}

1) Alslev, J. : Ztschr. ges. exp. Med. 120, 279 (1953).

2) Nelson, N. : J. Biol. Chem. 153, 375

(1944).

3) Somogyi, M. : J. Biol. Chem. 195, 19 (1952).

4) Roe, J.H. : J. Biol. Chem. 107,15 (1934).

5) Somogyi, M. : J. Biol. Chem. 86, 655 (1930).

6) 島溒, 清水 : 医学

と生物学 17, 102 (1950). 7) Woodward, H. (Jr.) : J. Clin. Invest. 31, 115 (1952).

Woodward, H. (Jr.) : Yale J. Biol. Med. 29, 335 (1956).

9) Root, H.F. : Amer. J. .Med. Soc. 211, 189 (1946).

10) Miller, M.J. : J. Clin. Invest. 31, 115 (1952).

11) Bollman, J.L. et al. : Amer.J. Physiol. 111, 483 (1935). $\quad$ 12) Bollman, J.L., Mann, F.C. : Amer. J. Physiol. 96, 683 (1931). 13) Reinecke, R.M. : Amer. J. Physiol. 136, 167 (1942). 14) Stewart, C.P., Thompson, J.C. : Biochem. J. 35, 245 (1941).

15) Cori, G.T., Cori, C.F. : J. Biol. Chem. 186, 763 (1950). 16) Leuthardt, F.E. et al. : Tagg. d. Schweiz. Physiol. u. Pharm., Geuf, 25 (1952). 17) Cori, G.T. et al. : Biochim. et biophys. acta 7, 304 (1951). 18) Park, C.R., Johnson, L.H. : Amer. J. Physiol. 182, 17 (1955).

19) Gammertoft, A.P. et al. : Acta Physiol. Scand. 8, 162 (1944). 20) Noah, G. : Ztschr. f. Klin. Med. 104, 150 (1926).

21) Alslev, J. : Ztschr. ges. exp. Med. 121, 1 (1953), 22.) Kosterlitz, H.W. : Biochem. J. 37, 322 (1943).

23) Leloire, L.F. et al. : Arch. Biochem. 18, 137 (1948). 24) Cardini, C.F., Leloire, L.F.: Arch. Biochem. and Biophys. 45, 55 (1953). 25) Leloire, L.F. et al. : J. Biol. Chem. 179, 497 (1949).

26) Leloire, L.F. et al. : J. Biol. Chem. 184, 333 (1950).

27) Leloire, L.F. : Arch. Biochem. and Biophys. 33, 186 (1951). 28) Kalcker, H.M. et al. : Nature 172, 1039 (1953). 29) Kalcker, H.M., Maxwell, E.S. : Biochim. et biophys. acta 22, 588 (1956).

30) Maxwell, E.S. : J. Biol Chem. 229, 139 (1957).

31)Kalcker, H.M. et al. : Science 125, 113 (1957). 